\title{
Art Mortgage Loan and its Positive Impact on the Art Market Revitalization
}

\author{
Kyoohoon $\mathrm{Jo}^{1}$, Jeongmin $\mathrm{Ko}^{2}$ \\ ${ }^{1}$ Student, Department of Culture and Arts Management, Hongik University, Korea, \\ jkh660210@naver.com \\ ${ }^{2}$ Professor, Department of Culture and Arts Management, Hongik University, Korea, \\ spin3001@naver.com
}

Corresponding author: Jeongmin Ko

\begin{abstract}
Due to the outbreak of the COVID-19 pandemic in 2020, there are fluctuations in the economy of the developed countries, changes in the government policies, cuts in the central bank interest rates, and easing in economic policies. However, unlike the recession in the real economy, stock price index and real estate prices are hitting all-time highs every day, and the art market is booming and art prices are skyrocketing. This is true for the Korean art market. However, in terms of GDP per capita, the Korean art market lags behind the world's major art markets. Rather than neglecting it as an autonomous structure within the art world, it is necessary to seriously consider what is needed for the quantitative and qualitative growth of the Korean art market from a financial, social, and policy perspective. Thus, this paper analyzed the 'activation of art loans' as a need for quantitative and qualitative growth of Korea's art market. The 'art', 'art market', 'art loans run for organization' , and 'art exchange' were analyzed in terms of market demand and supply. To this end, interviews with two major art institutions and loan cases from domestic and foreign advanced financial institutions were analyzed. Through this analysis, microscopically, it is necessary to 'lower the loan interest rate' and 'increase the period', 'the diversity of loan product composition', 'the expansion of the number of lending institutions', 'the professionalism of the borrowing institution members', and 'the loan acceptance of new artists' works', macroscopically, 'confirmation of the authenticity of artworks', 'mandatory disclosure of art transaction data', 'installation of art exchanges', 'calculation of art price index', 'creation of government funding', etc. were derived.
\end{abstract}

Keywords: Art Mortage Loan Market, Art Mortage Loan Interest Rate and Period, Art Mortgage Company, Art Exchange, Disclosure of Artwork Transaction Price, Art Price Index, New Artist Works, Policy Support

\section{Introduction}

\subsection{Research Purpose}

Asset markets such as stocks and real estate, which were feared to contract further due to the pandemic caused by the COVID-19 epidemic in the early 2020s, reached all-time highs due to the global government's fiscal expansion policy and the central bank's low interest rate policy. Korea's KOSPI and KOSDAQ indexes are also experiencing unprecedented prosperity. The real estate market is also booming. The Korean art market, which was expected to stagnate due to concerns about the

Received: May 09, 2021; $1^{\text {st }}$ Review Result: June 25, 2021; $2^{\text {nd }}$ Review Result: August 17, 2021 Accepted: September 30, 2021 
pandemic, has also addressed their concerns, and the works of famous artists are already sold out at galleries, auctions and art fairs, so some can only be purchased by making a reservation in advance. However, it is true that the reality of the Korean art market is much lacking compared to the current boom in the global art market. One of the necessary things to expand and revitalize the art market through is collateralized loans for art works and liquidity creation and demand expansion through them.

'Bell Epoque Asset Management's ART SIGNATURE2 professional investment private equity fund No. 3 (tentative name)[1]' was launched in 2020 with a one-year maturity, 5.35\% return, and a total fund of 10 billion won. This is significant in that it was established in Korea as an investment management company dedicated to art collateral loans, which were only partly incidental to existing banks and large auction houses, and launched an art collateral loan product. This can be seen as having a great meaning in that not only the commercialization of high-priced artworks due to the rapid rise in asset prices under the global low interest rate environment, but also the revitalization of art collateral loans activated in the advanced art market in Korea.

The US, UK, and E.U have revitalized their art markets, so new artists are also taking their place in the art market, although on a small scale. This is because the art collateral loan and the resulting credit creation contribute to the expansion of the art market. In the advanced art market, there is a widespread perception that the expansion of the art loan market is essential to the expansion of the overall scope of art.

Art loans are needed for the following reasons: First, the total amount of assets is large, but liquid capital is required due to lack of cash. Second, it is a case of generating profits from illiquid assets. Third, it is a case of using cash for another investment by securing liquidity of cash through art collateral loan.

Typically, a borrower who owns a lot of art but lacks cash is an inheritance in art and needs liquid capital to settle issues related to an upcoming property or other inheritance tax. In other cases, you may need a loan for the purpose of reallocating capital to purchase or invest in a new piece of art.

However, the research so far has been just a simple art value evaluation, but it has not been enough to make a real art collateral loan evaluation. The purpose of this study is to objectively evaluate the value of works of art, to establish a loan system, and to ultimately revitalize the art market. To do that, this differs from the art market and the art market loans What?, What institutions and companies carrying out works of art mortgage exists? Their loans, loan interest rates, the professional organization is different how? comparatively analyzed. The research method is a qualitative study, focusing on literature research and interviews.

\subsection{Research Scope and Composition}

The scope of this study aims to analyze the effect of art collateral loans on the revitalization of the art market.

For this purpose, this paper is organized as follows.

This differs from the art market and the art market loans What?, What institutions and companies carrying out works of art mortgage exists? Their loans, loan interest rates, the professional organization is different how? comparatively analyzed

Through interviews with two prominent Korean institutions, the limitations and desirable directions of the Korean art loan market were discussed, and effective measures were derived. 


\section{Theoretical Background}

\subsection{Art and Art Market}

\subsubsection{Characteristics of Artwork}

Artworks are less sensitive to the economy than other investment products such as stock prices and real estate, so they are less affected by the economy. Therefore, it can be an attractive investment product for those who want to form a diverse investment portfolio[2]. Because art provides not only economic motivation but also cultural factors that combine human appreciation and creative motivation, it can satisfy investors' aesthetic and speculative needs at the same time. Thus, art, as an investment instrument, has simultaneous benefits of four characteristics: artistic aspect, empirical aspect as an appreciation, possession aspect as a possession, and financial aspect as a result of rising prices of art.

The price structure of the artwork is not a general law of supply and demand, and supply is inelastic compared to demand. Suppliers and others decide on prices and consumers without impact. Due to this inelastic nature of supply, it is extremely dangerous for amateurs with no knowledge of art to directly purchase expensive artworks.

\subsubsection{Structure and Classification of Art Markets}

An art market is a place where sellers and buyers are connected to exchange ownership of works for a certain amount of money. The art market consists of producers, distributors, and consumers. To further classify, a producer is an artist of the art market; distributors are entities such as auctions and galleries; and consumers include collectors, museums, and corporations. There are also sectors that support supply, distribution, and consumption, formed by critics, consultants, and the media, to complement the art market. They participate directly in the market, but mostly through research and criticism, they exert a certain influence on the market[3].

Prior to the Renaissance, artists who were producers of the art market supplied their works to the market at the needs of consumers. Today, however, artists are now the leading producer of the art market.

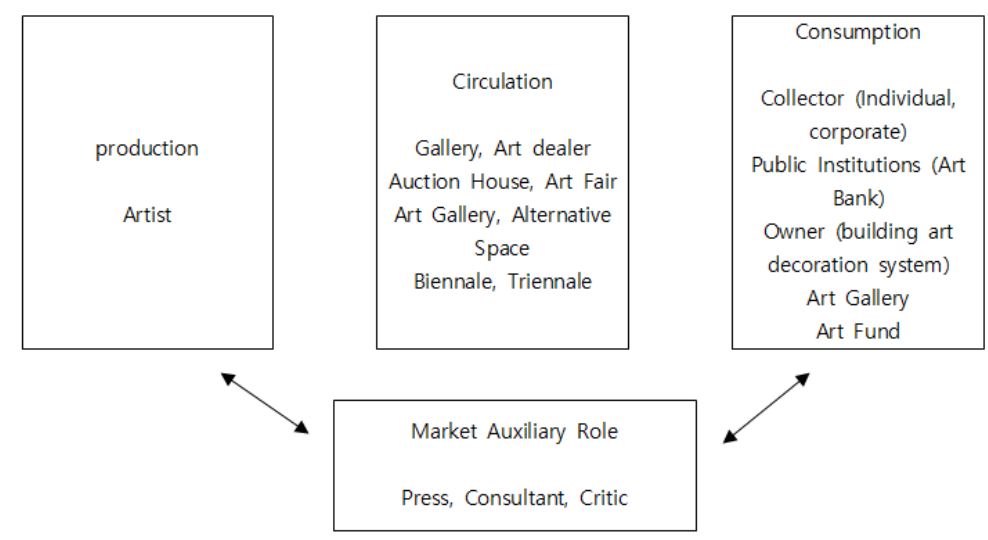

[Fig. 1] Structure of the Art Market

Source: Kim Bo-reum, ${ }^{『}$ New York Art Market $₫, 2010$, p.22.

The art distribution market may be divided into the primary art market, traded in galleries and the secondary art market, mainly for auction. These two markets help each other but maintain a strong competitive relationship and divide the galleries into public galleries and private galleries. Public 
galleries are galleries with the characteristics of museums, collections, and foundations for non-profit purposes, while private galleries are mostly private and while some are often commercial galleries for business purposes[4].

Unlike auctions in the secondary market, artists working in the primary art market, have an opportunity to enter the market and have a direct relationship[5]. Conversely, in the auction market, buyers and artists buy and sell goods through auction companies rather than directly selling between buyers and artists. After the work is released at an auction house, buyers decide on the ownership of the work through price competition.
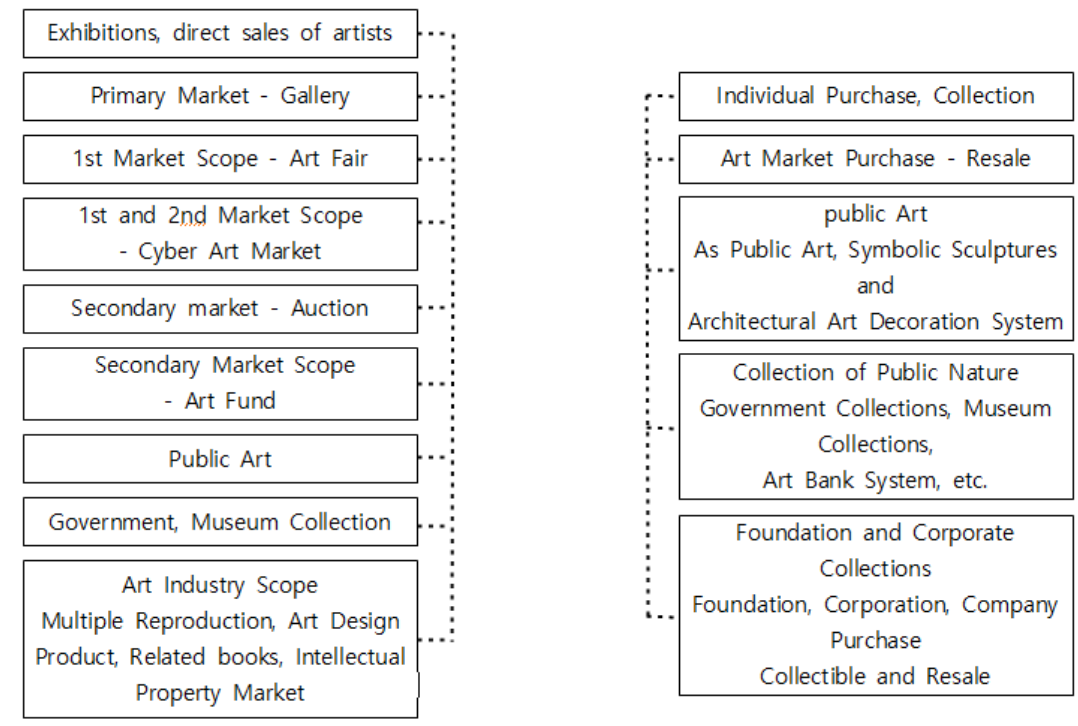

[Fig. 2] Art Market Classification and Purchase Type

Source: Choi Byung-sik, ${ }^{『} 2008$ Art Market and Art Dealers $₫$, p.23.

Price formation in the art auction market is determined through open competition among the auction participants, through a trading process between auction companies, vendors, and buyers. Participants in the auction will settle an amount including a certain fee at the time of winning the auction and transfer ownership of the artwork. The function of the art auction system in the art market is open price formation.

Auctions have transparency in terms of open and competitive selling methods. When the auction process and the auction results are released, the price is determined by competition among multiple buyers, so it is objective. In this regard, the art auction system has various positive effects, including fostering the art market, enhancing the public confidence in the price of art, improving the public confidence of art appraisal, and expanding the art market[6].

There are various types of art markets that play an important role in the art market, including galleries and auction markets, art fairs derived from the primary art market, art funds derived from the secondary art market, and cyber art markets formed in the primary and secondary art markets.

Art fairs play an important role in the art trade among art market participants, galleries, collectors, and large dealers. It started with the intention of protecting markets by checking auction houses, promoting and expanding transactions, and exchanging information between galleries.

Art funding begins in terms of what is considered an economic means of increasing the value of the artwork's future assets[7]. It is a form of investment in art such as stocks and bonds. Fund investors save money to share profits by selling artworks back to the market when they later rise in value. Participation costs and market variables are higher than other products. Art funds also attracted many 
people's attention because the art market has grown 8 to $13 \%$ annually over the past 25 years. Typical art funds include the British Rail Pension Fund and the Arts Fund. Furthermore, the development of Internet communication has led to the creation of cyber markets recently. As auction information was released on various auction sites, more people participated in cyber bidding to expand the auction market.

As mentioned earlier, it is common for art fairs to be classified as primary markets and cyber art markets to be classified as primary and secondary markets, but there are different views. Other art market classifications can be categorized into gallery (primary), auction (secondary), art fair (tertiary), and cyber (fourth)[8].

Art consumers can be divided as follows. The first is a public art museum with the public interest of local governments, the second is a buyer or the collector, and the third is a simple audience. Consumers here are collectors who purchase works, and their partnership with galleries strengthens their relationship. Art consumers have a huge impact on the overall art market[9].

\subsection{Current Status of Art Collateral Loans}

\subsubsection{Definition of Art Collateral Loans}

The art collateral loans mean that a person who owns an artwork has to set up a right of the pledge as collateral for the artwork in banks, large galleries, and auctions, paying a certain amount of interest and borrowing a certain amount of 40 to 60 percent of the auction price. In the case of such art collateral loans, works by famous artists who are traded at consistently high prices are mainly applied, and interest rates are set lower than other less famous works. New artists' works rarely apply to loans and famous works have higher collateral prices and lower interest rates than those of other industries.

\subsubsection{The Size of Art Collateral Loans}

According to the 'Art \& Finance Report 2019' published by Deloitte and Artistic, the world's art mortgage size as of August 2018 amounted to more than \$21 billion and less than \$24 billion. The total amount of art mortgages has grown by about 20 percent over the past five years. In Korea, Seoul Auction is also carrying out a mortgage on art, but the total amount itself is insignificant. According to the Financial Supervisory Service's electronic disclosure system (DART), the total amount of art collateral loans conducted by Seoul Auction with owners by the third quarter of 2019 was 8.184 billion won, which is low in comparison overseas (Bridge Economy 'Is art collateral available in Korea?').

\subsubsection{Structure of Art Collateral Loans}

First, the structure of art collateral loans, as a capital borrower of funds, consists of individuals and corporations including art holders, painters, distributors, etc. Rather than borrowing money by using art as collateral by painters and private collectors, large-scale distributors often do this when they need money. Second, as a lender of capital, there is a mortgagor, who lends money to art as collateral, such as an auction, a bank, and a large gallery. In Korea, Seoul Auction and others often lend money with their art as collateral. Third, in other cases, some financial entities, such as the 'Belle Epoque Asset Management Company', may make collateral loans for artworks in the form of funds, which may be activated in the future; in this case the fund beneficiary is considered to be the lender of funds for artworks. In recent years, Eco Capital's 'Eco-Rak Art Exchange' has used its platform to run loans and broker deals for new artists-oriented works.

\subsubsection{Major Domestic and Foreign Art Mortgage Companies}

Recently, the trade-in art works has been in the spotlight as a risk hedge compared to other financial 
products. Major lenders are as follows. First, there are financial institutions such as banks. As of 2017, private banks such as US Trust, Citi, JP Morgan, and Deutsche Bank had the most active collateral loans, bringing the total size to $\$ 15$ billion (17 trillion won), increasing sharply every year by $15 \%$. Second, there are large auction houses. Art collateral loans from auction institutions such as Christie, Sotheby's, Phillips, and Bonhams are also booming, and their size is $\$ 1.4$ billion (1.6 trillion won), growing 30\% every year. Third, institutions like Beautyk, etc. Art \& Finance Partners, Art Capital Group, Athena, etc. are growing at $15 \%$ over $\$ 1.2$ billion (1.4 trillion won) a year. Fourth, in the domestic case, loan execution companies are absolutely small compared to foreign countries, mainly auction companies such as Seoul Auction and Hana Bank, and primary financial sectors.

\section{Research Method}

\subsection{Literature Analysis}

\subsubsection{Domestic Cases}

\subsubsection{Seoul Auction Mortgage}

Seoul Auction is offering loans with art and antiques as collateral. If the owner inquires about the loan by e-mail and the person in charge of the mortgage loan replies whether it is possible, the loan will be executed by evaluating the price after receiving the actual work. In the case of domestic art collateral loans, Seoul Auction is the most active. It provides mortgage services to customers as a mortgagor. However, the size of mortgages for customers is dwindling. Until 2013, the accumulated amount of collateral loans exceeded around $\$ 9.4$ billion (9.4 billion KRW). Although there are some differences depending from year to year, since then, the amount of collateral loan has been decreasing. Furthermore, less than one percent of revenue is generated from mortgages versus gross sales. This suggests that Seoul Auction is reducing mortgage services as well as making little profit from collateral loans. For reference, few art collateral loans have been made at galleries, auction houses, and banks other than Seoul Auction.

[Table 1] Collateralized Loan Amount (Unit: KRW 1,000)

\begin{tabular}{|lc|}
\hline Year & Amount \\
\hline 2016 & $2,723,000$ \\
\hline 2017 & $4,507,000$ \\
\hline 2018 & $9,268,000$ \\
\hline 2019 & $4,472,000$ \\
\hline 2020 & $2,413,000$ \\
\hline
\end{tabular}

In the case of Seoul Auction, the annual interest rate is $12 \%$, the overdue rate is $15 \%$, the basic loan period is 6 months, the interest collection is preempted, and the mortgage rate is $150 \%$; this would seem too high, with the period is too short, and the amount of art collateral too low.

[Table 2] Conditions of Mortgage Loans for Artworks

\begin{tabular}{|cc|}
\hline Division & General mortgage loan \\
\hline Interest rate & $12 \% /$ year \\
\hline Delinquent interest rate & $15 \% /$ year \\
\hline Basic loan period & 6 months \\
\hline Interest collection & Principle: Preemption \\
\hline Set & $150 \%$ \\
\hline
\end{tabular}


In addition, some of the winning bids will be provided as collateral loans to auction winning customers. These are divided into four stages: less than 50 million won, less than 100 million won, less than 200 million won, and more than 200 million won.

[Table 3] Step-by-step Content of Auction Loans[10]

\begin{tabular}{|c|c|c|c|c|}
\hline Winning bid & $\begin{array}{l}50 \text { million } \\
\text { won or less }\end{array}$ & $\begin{array}{c}1 \text { billion } \\
\text { won or less }\end{array}$ & $\begin{array}{l}2 \text { billion } \\
\text { won or less }\end{array}$ & 2 billion or more \\
\hline Loan limit & $\begin{array}{l}50 \% \text { of the winning bid } \\
\text { price }\end{array}$ & $\begin{array}{l}30 \% \text { of the winning bid } \\
\text { price }\end{array}$ & $\begin{array}{l}20 \% \text { of the winning bid } \\
\text { price }\end{array}$ & \\
\hline Loan limit amount & 25million won & 30million won & 40million won & 50million won \\
\hline Interest rate & $12 \%$ & $12 \%$ & $12 \%$ & $12 \%$ \\
\hline Delinquent interest rate & $15 \%$ & $15 \%$ & $15 \%$ & $15 \%$ \\
\hline
\end{tabular}

\subsubsection{Bell Epoque Asset Management's ART SIGNATURE II Specialized Investment Criminal Equity Fund No. 3}

The fund is a structured system in which artworks in large domestic and foreign galleries, auction houses, and boutique are regarded as collateral and is carried out to receive interest on them.

The legal entity of the mortgage agreement (acquisition of private equity bonds) is the fund (taking over private equity bonds, holding collateral, and acting as a managing entity) and the potential investor submitting the purchase commitment to the fund is Seoul Auction Co. Ltd., the largest art auction company in Korea. In the event of a default situation of the borrower, Seoul Auction Co. Ltd. will exchange confirmation of the purchase by the individual purchase commitment for the secured work.

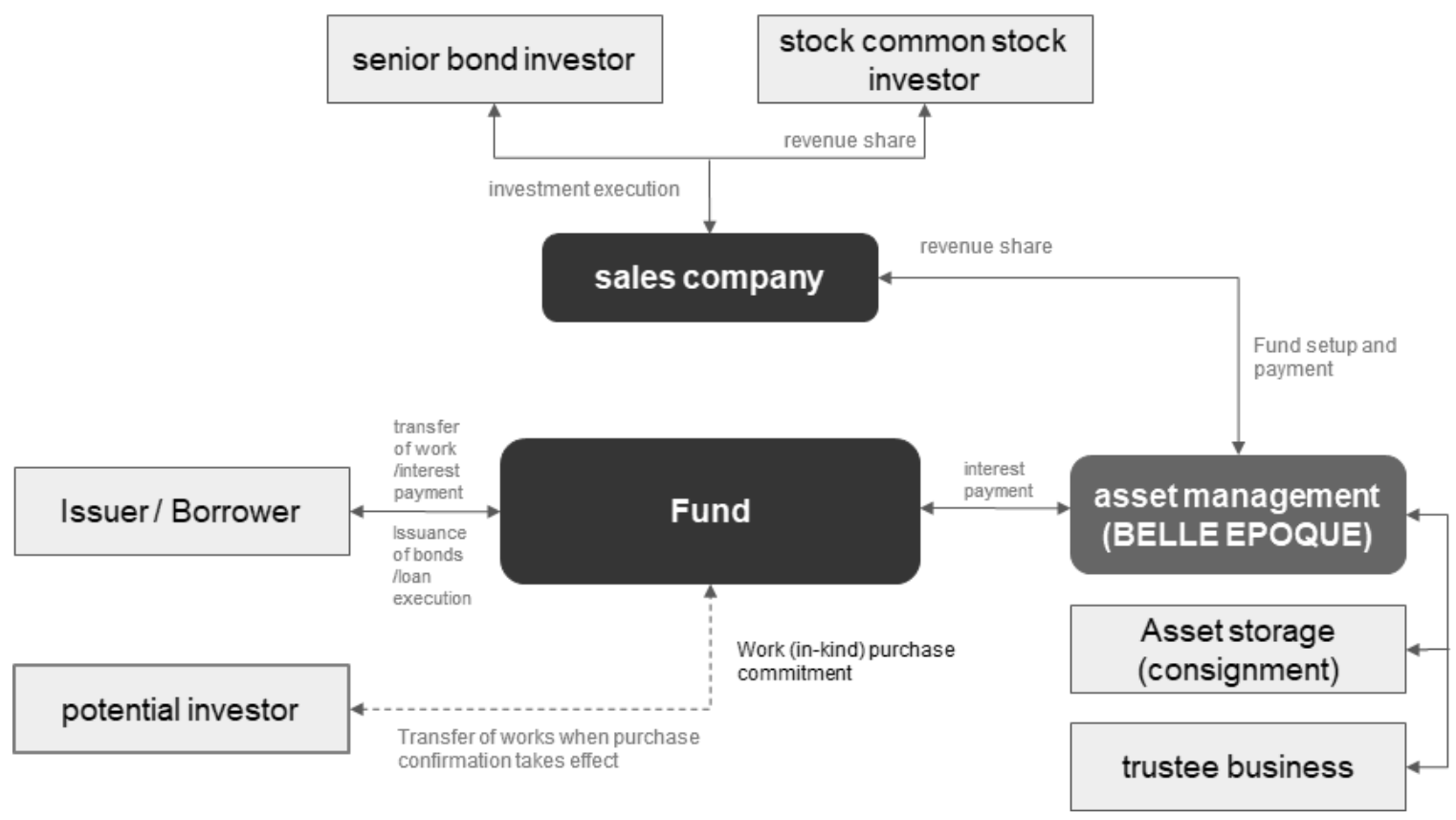

[Fig. 3] ART SIGNATURE $\square$ Professional Investment Criminal Fund No. 3

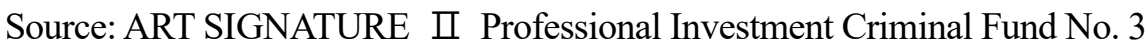

The types of private equity bonds issued for each purpose are as follows:

i) If there is a time difference between the prospective seller and the prospective

buyer, the broker first buys the work through borrowing and then sells it to the prospective buyer. 
ii) Where work exists for distribution and inventory, collateral and bonds for non-distribution artworks shall be issued to secure financial resources to purchase artworks for distribution.

iii) Securing loan brokerage fees and financial services by borrowing capital from the outside in consideration of demand for funds.

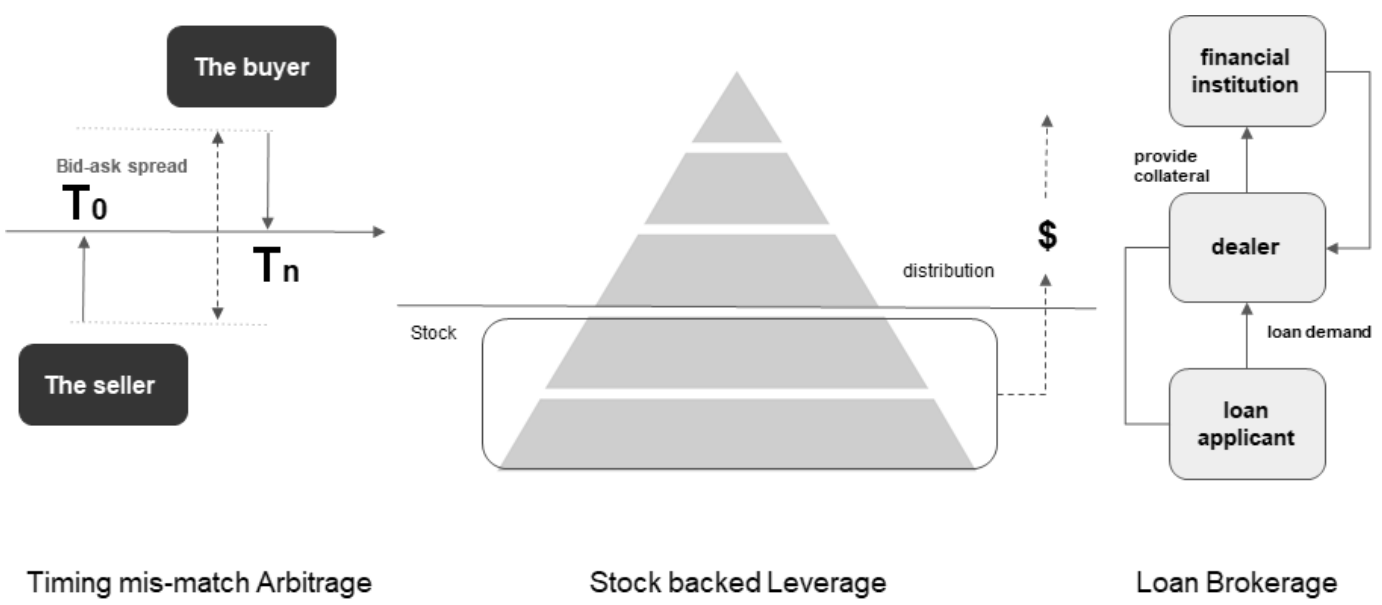

[Fig. 4] ART SIGNATURE $\amalg$ Professional Investment Criminal Fund No. 3

Source: ART SIGNATURE ㅍ Professional Investment Criminal Fund No. 3

Belle Epoque ART SIGNATURE II Specialized Investment Fund 3 selects more than $50 \%$ of designated works with a one-year maturity, minimizes investment execution, and has an annual return target of 5.35\% (based on investment principal after deducting fees) and 5.0\% principal loss defenso (loss defense through investment in two types of profitable securities).

[Table 4] ART SIGNATURE $\square$ Professional Investment Criminal Fund No. 3

\begin{tabular}{|c|c|}
\hline Division & Main Content \\
\hline Product name & ART SIGNATURE II Professional Investment Criminal Fund No. 3 \\
\hline Investment target & $\begin{array}{l}\text { Art work collateralized loan/private equity fund, Art Signature } 2 \text { types of beneficiary rights and } \\
\text { works of art for the purpose of profit-seeking sale }\end{array}$ \\
\hline Fund type & $\begin{array}{c}\text { Professional investment type private placement fund, private, kind, mixed asset type, unit type, } \\
\text { closed type }\end{array}$ \\
\hline Recruitment scale & Up to KRW 10 billion \\
\hline Fund establishment date & April 2020 \\
\hline Fund Maturity & 1 year from the date of establishment \\
\hline Target rate of return & $5.35 \%$ per annum (after deduction of fees) \\
\hline Total pay & TBD (excluding upfront fees) \\
\hline Upfront/Sales Fee & TBD (Vendor Determination) \\
\hline Operation fee & $0.5 \%$ per year \\
\hline Other remuneration & $\begin{array}{l}\text { Trust remuneration } 0.04 \% \text { per year, office trust remuneration } 0.05 \% \text { per year, insurance premium } \\
\qquad 0.12 \% \text { per year, transportation and storage charges } 0.03 \% \text { per year }\end{array}$ \\
\hline Mid-term redemption & No mid-term redemption \\
\hline
\end{tabular}




\subsubsection{Eco-Rock Art Exchange}

EcoCapital created its own platform, EcoRock 'Art Exchange', in addition to the existing feed and poultry loan business. The new platform allows new artists to sell their works on its platform and allows buyers to purchase the art on interest-free installments for 36 months. Recently, the number of views has been activated with 5,000 to 10,000 views.

\subsubsection{Overseas Cases}

According to the Art \& Finance Report published by Deloitte in 2017, U.S. Trust, Citi Private Bank, JP Morgan Bribit Bank, and Deutsche Bank Private Wells Management are the most active in the civil bank art collateral service area. The total amount is about $\$ 15$ billion, growing about 15 percent annually.

On the other hand, there are also active collateral loans from auction institutions such as Christie, Sotheby, Phillips, and Bonhams. The size of the field is about $\$ 1.4$ billion (1.6 trillion KRW) and the average annual growth rate is about $30 \%$.

It is also worth paying attention to the Boutique Loan Institution's Art Collateral Loan. It is led by Art \& Finance Partners, Art Capital Group, and Athena. It is also making \$1.2 billion (1.4 trillion KRW) and growing at an average of $15 \%$ annually.

For the primary financial sector, art collateral is not attractive. The value of the artwork changes from time to time, and it is difficult to write a contract because there are many poisonous clauses. However, as shown above, foreign primary financial institutions (private banks) are actively borrowing art collateral. The reason can be speculated according to Citi Bank's art collateral case. Private bank art loans are made not for consumers' reasons, but by general corporate financial loans that continue as an extension of the business. Artworks are recognized as owned by consumers, and the loan structure is similar to existing loan models, such as loans that can be repaid through borrower guarantees.

\subsubsection{CitiBank}

CitiBank created the Citi Art Advisory Service in 1979 by recruiting experts to provide artspecialized services. This is sometimes seen as the beginning of collateral on art. At that time, the minimum loan was $\$ 5$ million (5.8 billion won), and the minimum value of the artwork provided by the owner as collateral was about $\$ 0.2$ million ( 230 million won).

Art collateral screening is conducted in a similar way to unsecured loans. They put a great deal of weight on the 'evaluation of financial soundness' of borrowers as well as on the marketability and value of artworks. Citibank considers the borrower's ability to pay back when it comes to art collateral loans. The reviewer also assesses the borrower's underlying assets and liabilities and conditional obligations to approve the loan.

If the loan is approved, Citibank estimates its value through the Fair Market Value (FMV) presented by the art expert. The interest rate has been set at Libor or about $1 \%$ more. The period is one to two years, and the amount of the loan is up to $50 \%$ of the value of the art. It is natural that investors who want a risk hedge on such well-established art collateral loans gather attention. The 9th edition of the Uniform Commercial Code (UCC) prepared by the U.S. government has created an environment favorable to the market by establishing art security safety devices. On this basis, the U.S. art mortgage and the trading market have grown[11].

Banks value the 'financial situation or credit rating' of borrowers when lending art collateral. Auction companies and boutique lenders differ in that they focus on the "value of art" held by borrowers. 


\subsubsection{Athena Art Finance \& Borro Private Finance}

Athena Art Finance, a well-known boutique lender, was founded in 2015 by Andrea Denase and is headquartered in New York City. They are independent financial firms specializing in blue chip art collections. The agency calculates up to '50\% of the value of the artwork' to be collateralized as loanable. The period should be six months to seven years, and the amount should be at least $\$ 1$ million (1.18 billion won).

Athena Art Finance has two missions. The first is to create a larger art capital market through art as an asset. And by continuing to specializing and institutionalizing this, the conversion of art as securities into loan is possible.

Borro Private Finance, which has branches in London, New York, and Los Angeles, offers art loans not only offline but also online. It is a company that operates art funds and proposes various investments such as mortgage loans for "high-end assets" such as classical cars, jewelry, and watches in addition to artworks.

\subsubsection{Sotheby Art Finance}

Sotheby's, one of the most famous auction houses in the United Kingdom, is a historic site founded in the 18th century. It has offered mortgage loans for 25 years. Sotheby's explains the conditions of the artwork to be secured by pure art, photography, decorative art, and jewelry art, such as paintings and sculptures that are valuable as collections. Sotheby's art collateral scheme is 'short-term prepayment by consignment'. There is also a standard of ' $40 \%$ to $60 \%$ of the total auction estimate' for secured artworks. The company has provided $\$ 4$ billion worth of art loans so far. Unlike the U.S. and Britain, many art mortgages do not take place in Europe, which is called the home of art. This is because the European industry's view of art loans is negative as if it were "going to a pawnshop to make money." In this respect, the Korean art mortgage market should refer to the United States because it has abundant liquidity and efficiency. In the U.S., there is also a "UCC Legal Allocation" in which the collateral is registered, and the lender owns the collateral. Due to this allocation, art owners can easily get a loan. In Korea, most of the art collateral loans are made through auction companies. Even that size is decreasing every year. If there is a successful best practice of lending art collateral, it will be able to solve the risks that Korean art investors are concerned about and change this aspect.

\subsection{Interviews}

\subsubsection{The Interview with Director Kang}

The interview with Kang Hee-kyung, director of the National Museum of Modern and Contemporary Art on February 24,2021, is as follows.

First, if it is judged to be a forgery, the famous artist who drew the original article may state that it is genuine. Why does this happen?

"In the case of a well-known author, if it is a forgery from the author's point of view, the credibility of the works that the author has already reviewed may drop to the bottom, and the market itself may be shaken. so maybe they said it was genuine. Also, in the case of older writers, there are very few people who have properly built their own archives, so it is difficult to judge a forgery based only on their own memories. There are many cases where the bereaved families see their appraisal, but in many cases they do not know (there is no problem if the archive is properly created), so they entrust the association's evaluation.

Second, some say that the art market where many counterfeits are circulated is called an advanced art market because there are many famous artists. What is your opinion?

"My opinion is the opposite. The fact that a lot of counterfeiting is traded is an opinion that there are 
many loopholes and the appraisal function is not working properly. This is especially true when the number of artists traded is limited like in Korea. There are only about 200 actively traded artists, but I think that the fact that the works of these artists are not properly appraised proves that they are only buying expensive works, and that basic research, investigation, and archives on the authors are weak."

\subsubsection{The Interview with CEO Jang}

The interview with CEO Jang Hyun-geun of Eco Capital, who created 'Art Exchange', the platform of Eco Rock Gallery on April 20,2021, is very meaningful.

First, what are the conditions that can activate art collateral loans and the resulting art transactions?

"I think the most important thing is the transparent disclosure of the price of artworks. Because the correct collateral value is necessary to set the loan amount of the art work, I think that ultimately art trade can also be activated."

Second, why do you think the price of art works is not transparent or there is a difference between the actual transactions and the existing art collateral loans?

"I think it's probably due to a number of subtle causes of expensive art. However, it can be presumed that the price of art works has not been transparently traded due to the tax issue mentioned last among them, such as the anonymity of the collector, the commission of the intermediary dealer, and the reduction of the profit tax on the transfer of art."

In particular, for art collateral loans to be activated, 'calculation of art price index' must be preceded. To do this, the existing auction data must be transparently disclosed, but the data of Seoul Auction and $\mathrm{K}$ Auction is not disclosed or it is not easy to calculate an accurate art price index. However, the development of the Korean art information system (K-Artmarket) and the Korean art price index (K-Artprice Index) can have a positive effect on the collateral calculation for art collateral loans. If the government enforces the incompleteness of the two indices mentioned above with support and administrative orders, a more complete 'art price index' can be produced, and the art collateral loan market can be activated by calculating realistic collateral based on it. In addition, it is still insufficient to calculate the overall art price index by looking at only the actual transaction prices of auction companies that disclose domestic artworks because their auctions are smaller than those of galleries, but do not disclose them transparently.

\section{Efficient Way to What?}

\subsection{Efficient Way}

After reviewing the various factors studied in the previous chapter, the effective method for the revitalization of the art mortage loan is as follows.

\subsubsection{The Gap between Existing and Emerging Artists should be Narrowed.}

The works of up-and-coming artists must also be priced at a minimum as a product for sale or loan. Like the YBA (British Artists Movement) movement developed by Damien Hirst and Sarah Zuckers in the late 1980s in England, the works of up-and-coming artists should be activated and the value of collateral should be increased in Korea due to epochal changes. This is something that the government, academia, and financial circles should all work together to make efforts, but it is only possible when famous writers give up their vested interests.

For example, 'Eco Capital' brokers supports the works of up-and-coming artists to turn the entire second floor into a gallery, and provides a loan service for the purchase of artworks in a 36-month interest-free installments to the buyer. The delinquency rate for three years is only about $1 \%$, so there 
are no defects in operation.

Considering that the general business of a capital company is credit, if a large number of capital companies can implement art loan service in the art sales of up-and-coming artists, such as car installment financing companies can, the art loan market for up-and-coming artists will be activated, which in turn will stimulate the art transaction. It will play a role in facilitating and increasing the scale significantly.

\subsubsection{Mandatory Disclosure of Art Transaction Data}

Of course, if it is legally obligatory to disclose art transaction details, the art market can shrink, but if it is combined with taxation and supportive policies as much as possible, it can be activated without being contracted. If it is necessary to transparently disclose all transaction details while raising the non-taxable amount of up to 60 million won to 100 million won, collateral for similar art works may be advantageous for appropriation.

The main reason why Korean art transactions have been reduced and not disclosed is for tax evasion by the chaebol and the wealthy, and one of them is their reluctance to expose as a tax base .In this way, when the art transaction data is made public, the price of the art work as well as other similar works that are not traded can be determined by inferring. In other words, it is possible to set the price in comparison with the works of the same artist, so that the collateral value of the art work can be easily determined and the art collateral loan can be activated.

\subsubsection{Establishment of Art Exchange}

The 'Art Exchange' provides real-time transaction prices for artworks. The auction prices of Seoul Auction and $\mathrm{K}$ Auction are disclosed even if they are opaque, but it was impossible to know the sale price of art works in the gallery. However, if the art transaction is established in the form of an 'application', not only the information on the already sold art but also the information on the art being sold can be exposed to anyone. Not only works information (title, artist, material, work size, production year, work image), art price, and sales, but also virtual exhibitions, evaluation of works, and actual transaction pricescan be closely observed.

A research should pay attention to the 'art exchange application app', that is, the 'platform' provided by 'EcoRock Gallery' recently established by 'Eco Capital,' a subsidiary of Harim.

\subsubsection{Calculation of Art Price Index}

If the 'disclosure of art transaction data is obligatory' in $\mathbf{4 . 2}$, it is easy to calculate the art price index. If we can create a Korean art index like the May-Moses index with Sotheby's, which was created jointly by New York University professors Jianping Mei and Michael Moses, it could be absolutely advantageous in calculating the collateral value of art works and would be of great help in revitalizing the art market. However, as a prerequisite, the price index of Korean art works can be calculated by the repeat sales model only when the art transaction data is transparently disclosed. This is because the reliability of the Korean art price index based on the existing hedonic model is significantly lowered. If a 'K-Art price index' in Korea such as the KOSPI and KOSDAQ indexes can be developed, the collateral value of artworks can be easily determined. Just as Samsung Electronics' stocks are collateralized up to $75 \%$ of the market price, the collateral price of Lee's works can be easily determined.

The existing Korean art market information system (K-Artmarket, www.k-artmarket.kr) and KArtprice (K-artprice.newsis.com) of Newsis and Korea Art price Appraisal Association do not have enough data. Data after January 2019 cannot be found in the Korean art market information system. KArtprice is collecting the latest data, but unfortunately, it only provides data on the transaction price of 
artworks since 2015 for '200 famous artists' inside and outside Korea. Considering that artworks have been traded through auctions in Korea since 1998, the amount of data from these two institutions is insufficient.

\subsubsection{Establishment of a Certain Fund under the Jurisdiction of the Ministry of Culture, Sports and Tourism}

Although it is a resolution of the National Assembly, the Ministry of Culture, Sports and Tourism create a 'fund to a certain extent to purchase artworks' and inevitably reflect the government's active policy to repurchase insolvent art collateral within a certain limit for a valid reason introduction. This can be a good example in the case where a neighboring country such as China, and France in Europe, supported its own artists and their works through policy to revitalize and nurture the art market.

\subsection{Limitation}

Various factors can be considered as the limitations of Korea's art collateral loans, but the 'lack of objectivity in art evaluation' and 'lack of professionalism of commercialized art management institutions' can be viewed as limitations.

\subsubsection{Lack of Objectivity in Art Evaluation as a Prior Factor}

In general, the items that must be referred to in the appraisal of works of art include 'the artist's career and awareness', 'the artist's history and number of exhibitions', 'the size of the work, that is, per piece of art', and 'the value of the work'[12]. However, there is a lack of professional between human and material systems that can objectify these factors.

\subsubsection{Lack of Professionalism of Management Institutions for Artworks as Post-factor}

In the case of art funds and art loan funds, which are emerging as popular products in the US and Europe, they play an important role in fund approval and management, as experts who majored in art finance are located in the management and supervision departments of Citi bank and JP Morgan. However, in Korea, the majority of people majoring in stocks and bonds are those who are not in the art field, so the PBS (Prime Brokerage Service) and custodial bank cannot play their role when forming an art fund.

Therefore, the art collateral loan market should be activated through continuous research that can supplement the above limitations and the efficient measures derived above, so that it can contribute to the increase in the price of art works and the revitalization of the art market.

\section{Conclusions}

Various factors are necessary for the qualitative and quantitative growth of the art market by activating collateral for art works, but the results of the previous study can be divided into a microscopic view limited to the art loan market and a macro view under the overall social structure.

\subsection{A microscopic Point of View}

Overseas and domestic art collateral lenders are focusing on 'Security Loan Interest Rate and Period', 'Security Loan Product Composition', 'Diversity of Mortgage Institutions', 'Professionalism of Mortgage Institutions', and 'Possibility of Loan by New Artists', etc. There is a clear difference among 
them.

\subsubsection{Interest Rate and Term}

Domestic institutions have lower collateral, higher interest rates, and shorter loan terms than foreign institutions. This is a proof that, in general, Koreans have a more conservative view on art than overseas, and that they perceive that there is a lot of risk.

\subsubsection{Composition of Loan Products}

Overseas, art collateral loans are diverse, such as blue chips, new works, sculptures, photos, and jewelry, but in Korea, loans are limited to some expensive blue chips.

\subsubsection{Diversity of Lending Institutions}

Overseas, institutions that issue art collateral loans are diverse, such as the 1st financial sector, the 2nd financial sector, and the boutique, but in Korea, it is extremely limited such as Seoul Auction and some large banks.

\subsubsection{Professionalism of Lending Institution Members}

Most of the members of the overseas art loan review and execution team are art and finance majors, so they have expertise in art and general financial knowledge.

\subsubsection{Possibility of Lending Work by Emerging Artists}

In foreign countries, of course, collateral loans are carefully executed for the works of up-andcoming artists, but there are hardly any restrictions as in Korea. Another reason for this is that the social atmosphere and the role of the government in Korea are inferior compared overseas.

\subsection{A Macro Point of View}

In order for the art market to grow qualitatively and quantitatively by activating collateral for art loans, it is necessary to check whether the art works subject to the collateral loan are genuine, and the correct value of the art work must be set appropriately.

\subsubsection{Confirmation of the Authenticity of the Artwork}

The issue on whether the art work is genuine can be easily resolved by collecting and keeping the original archives of the works at the evaluation institution and presenting it as evidence when there is a dispute over the authenticity, but it is rare for older artists to have an archive. However, these days, the information and communication field is highly developed, so it does not seem too difficult to go through a unique identification process.

\subsubsection{Mandatory Disclosure of Art Transaction Data}

In this way, when the art transaction data is made public, the price of the art work as well as other similar works that are not traded can be determined by inferring.

\subsubsection{Establishment of Art Exchange}

If the art transaction is established in the form of an 'application', not only the information on the already sold art but also the information on the art being sold can be exposed to anyone. 


\subsubsection{Calculation of Art Price Index}

If a 'K-Art price index' in Korea such as the KOSPI and KOSDAQ indexes can be developed, the collateral value of artworks can be easily determined. Just as Samsung Electronics' stocks are collateralized up to $75 \%$ of the market price, the collateral price of Lee's works can be easily determined.

\subsubsection{Establishment of a Certain Fund under the Jurisdiction of the Ministry of Culture, Sports and Tourism}

Although it is a resolution of the National Assembly, the Ministry of Culture, Sports and Tourism create a 'fund to a certain extent to purchase artworks' and inevitably reflect the government's active policy to repurchase insolvent art collateral within a certain limit for a valid reason introduction.

\section{References}

[1] https://www.edaily.co.kr/news/read?newsId=01200486622589288\&mediaCodeNo=257\&OutLnkChk=Y, Aug 20 (2019)

[2] Park Ji-hyon, Shin Hyeong-deok, Would online artwork auction be better than offline? Focusing on the impacts of price determinants on the fetching price, Business Studies of Korea Management Association, (2012), Vol.41, No.4, pp.789-808, UCI : G704-000126.2012.41.4.006

[3] Kim Bo-reum, New York Art Market, Art and Culture, (2010), pp.22-23, http://www.kyobobook.co.kr/product/detailViewKor.laf?ejkGb=KOR\&mallGb=KOR\&barcode=9788991847712\#

[4] Kyoo-Hoon Jo, Analysis Study on Factors Forming the Price of Chinese Artwork, Kyung Hee University Graduate School of Business, Master's thesis, (2018)

[5] Choi Byung-sik, Art Market and Art Dealer, Dongmunseon, (2008), pp.23.

[6] Kim Tae-seong, A Study on Art as Investment and Art Price Formation Factors, Yonsei University, Master's thesis, (2008), pp.21-22.

[7] Eunjung Kwon, A Study on the Current State of Domestic and Overseas Art Funds, Journal of Arts Studies, (2009), Vol.15, pp.121-152.

[8] Kyoo-Hoon Jo, Analysis Study on Factors Forming the Price of Chinese Artwork, Kyung Hee University Graduate School of Business, Master's thesis, (2018), pp.15.

[9] Euijeong Lee, A Study on Price Formation in the Contemporary Art Market, Dankook University Graduate School of Popular Culture and Arts, Master's thesis, (2008), pp.6.

[10] https://www.seoulauction.com/service/page?view=securedLoan, May 10 (2020)

[11] http://it.chosun.com/site/data/html_dir/2019/06/20/2019062001097.html?form=MY01SV\&OCID=MY01SV, June 20, (2019)

[12] http:/thebell.co.kr/free/content/ArticleView.asp?key=202104201027492680104975\&lcode=00\&page $=5 \&$ svccode $=$ 00, May $22(2021)$ 